\title{
Experimental susceptibility of turbot Scophthalmus maximus to viral haemorrhagic septicaemia virus isolated from cultivated turbot
}

\author{
M. Snow*, D. A. Smail \\ FRS Marine Laboratory, PO Box 101, Victoria Road, Torry, Aberdeen AB11 9DB, Scotland, UK
}

\begin{abstract}
Juvenile pathogen-free turbot were infected with a viral haemorrhagic septicaemia virus (VHSV) isolate recovered from turbot cultivated on the island of Gigha, West Scotland. Mortality of $100 \%$ was recorded in fish infected via the intra-peritoneal (i.p.) route. Horizontal transmission of VHSV in sea water was demonstrated by cohabitation of naive fish with i.p. infected fish at a ratio of $1: 1$. The total cumulative average mortality in cohabiting fish was $60 \%$ by $60 \mathrm{~d}$ post-infection. Turbot infected via an immersion route exhibited a cumulative average mortality of $71 \%$ by the end of the experiment. VHSV identified by enzyme-linked immunosorbent assay (ELISA) was recovered from both organ (kidney and spleen) and brain samples of individual fish that died following infection by all experimental routes. These findings pose significant implications regarding the persistence of VHSV and its role in limiting natural populations of marine fish species. In addition, the establishment of infection models for the transmission of VHSV in sea water is of fundamental importance to the development of anti-VHSV vaccines in important commercial species such as turbot.
\end{abstract}

KEY WORDS: Viral haemorrhagic septicaemia virus - VHSV · Rhabdovirus - Novirhabdovirus - Turbot

\section{INTRODUCTION}

Traditionally, viral haemorrhagic septicaemia (VHS) was considered to be a disease of rainbow trout Oncorhynchus mykiss, which has caused extensive losses to culture operations in continental Europe (Wolf 1988) Since the early 1990s, however, VHSV has been increasingly isolated from a wide range of wild marine fish species, indicating the existence of an enzootic virus in both the North American and European marine environments (Meyers \& Winton 1995, Smail 1995, Dixon et al. 1997, Mortensen et al. 1999). Furthermore, in recent years, outbreaks of VHS have occurred in turbot reared in intensive culture in West Scotland (Ross et al. 1994) and in South West Ireland (McCardle unpubl.). Evidence based on nucleotide sequencing analysis has identified a similarity between these viruses causing epizootics in farmed tur-

·E-mail: snowm@marlab.ac.uk bot and isolates recovered from wild fish in the North Sea (Stone et al. 1997, Snow et al. 1999). Thus, the origin of virus responsible for mortality in cultivated turbot appears to be the marine environment. The existence of a marine reservoir of virus highlights a potential threat to the future of commercial production of both turbot and other marine fish species in Europe.

The fact that marine fish species are susceptible to VHSV has been known for some years. Indeed, a number of species including Atlantic salmon Salmo salar (de Kinkelin \& Castric 1982), sea bass Dicentrarchus labrax and turbot Scophthalmus maximus (Castric \& de Kinkelin 1984) have been shown to be susceptible to VHSV by experimental infection. The VHSV isolates used in these experiments, however, originated in rainbow trout cultured in Continental Europe. To date, few studies have investigated the susceptibility of marine fish to isolates recovered from homologous host species. The first study to address this issue was performed by Kocan et al. (1997), who demonstrated the susceptibility of Pacific herring Clupea pallasi to a 
VHSV strain recovered from wild herring in Puget Sound, Washington, USA. These findings suggested that VHSV could be an important natural pathogen for Pacific herring. The role of marine VHSV in causing mortality among other marine fish species from which VHSV has been isolated remains unknown.

The current interest in commercial farming of marine fish species, coupled to the lack of a proven commercially available vaccine against VHSV, has rendered the susceptibility of marine fish species to VHSV an important issue. The aim of this study was to investigate the experimental susceptibility of turbot to a VHSV isolate recovered from turbot farmed in Scotland. In addition to assessing the potential threat to future culture operations by the existence of a marine reservoir of virus, such knowledge may also permit insight into the potential role of VHSV in affecting wild fish stocks in the marine environment.

\section{METHODS}

Cell culture and virus propagation. The isolate of VHSV used in this study was 860/94, which originated from turbot farmed at Gigha, West Scotland (Ross et al. 1994).

The epithelioma papillosum cyprini (EPC) (Fijan et al. 1983) cell line was used to propagate virus. Cells were grown at $23^{\circ} \mathrm{C}$ in Glasgow modified minimal essential medium supplemented with $10 \%$ foetal bovine serum (GMEM-10) (Life Technologies). Stock virus was produced from virus stored following 2 passages on EPC cells. For production of virus, cell cultures were inoculated with virus at a multiplicity of infection of 0.01 , and held at $15^{\circ} \mathrm{C}$ until the production of cytopathic effect (CPE). Virus was then stored at $-80^{\circ} \mathrm{C}$ and an aliquot titrated following a single freezethaw cycle. Virus titration was performed using the tis- sue culture infectious dose method $\left(\mathrm{TCID}_{50}\right)$ in EPC cells (Reed \& Muench 1938, Burleson et al. 1992).

Pathogen-free fish. Certified disease-free turbot (mean weight $8 \mathrm{~g}$ ) were obtained from a commercial supplier (Maximus A/S, Gudnaesstrandvej 17, 7755 Bedsted Thy, Denmark). Prior to infection, 10 fish were killed and the organs (kidney, liver and spleen) of individual fish removed and screened for the presence of VHSV, infectious pancreatic necrosis virus (IPNV) and infectious haematopoietic necrosis virus (IHNV). Tissue samples were homogenised and diluted 1:10 (w/v) in GMEM-10 supplemented with $0.2 \%$ gentamycin. EPC cells were grown on 24 -well plates to a confluency of 60 to $80 \%$, and individual wells were inoculated with tissue samples prepared as above to final dilutions of $1: 100$ and $1: 1000$. Plates were incubated at $15^{\circ} \mathrm{C}$ for $7 \mathrm{~d}$, and examined under $\times 40$ magnification on an inverted microscope (Nikon Diaphot) for CPE. An aliquot of cell culture supernatant was then removed and diluted $1: 100$ and $1: 1000$ on a fresh 24 -well plate and the remainder stored at $-80^{\circ} \mathrm{C}$. Following a second incubation for 7 d at $15^{\circ} \mathrm{C}$, cells were again screened for the presence of CPE.

Infection of turbot with VHSV isolate $860 / 94$. Turbot were stocked in eight $30 \mathrm{l}$ aquaria supplied with flow rates of $1 \mathrm{l} \mathrm{min} \mathrm{m}^{-1}$, at a density of 30 fish per tank, and allowed to acclimate for $7 \mathrm{~d}$ prior to infection. Water temperatures were maintained at approximately $10^{\circ} \mathrm{C}$ for the duration of the infection. Fish were starved for $24 \mathrm{~h}$ prior to infection which was performed via intraperitoneal (i.p.), cohabitational and immersion routes.

From each of 3 tanks, one-half of the fish were removed (15 fish), anaesthetised and injected i.p. with VHSV strain $860 / 94$. The inoculation volume was $100 \mu \mathrm{l}$, representing a dose of $2 \times 10^{7} \mathrm{TCID}_{50}$ per fish. These i.p. injected fish were marked by clipping the caudal fin, and returned to their original tank to cohabit with the remaining fish at a ratio of 1 VHSV

Table 1. VHSV infecting Scophthalmus maximus. Summary of results obtained from the challenge of turbot with VHSV isolate 860/94. All subsamples of organ and brain pools producing a cytopathic effect (CPE) in tissue culture were positive for VHSV by ELISA. A single control fish which died was negative for virus by both culture and ELISA

\begin{tabular}{|c|c|c|c|c|c|c|c|c|c|c|}
\hline \multirow[b]{2}{*}{ Total number of fish } & \multicolumn{2}{|c|}{$\begin{array}{l}\text { i.p. } \\
\text { Mortalities Survivors }\end{array}$} & \multicolumn{2}{|c|}{$\begin{array}{l}\text { Cohabitation } \\
\text { Mortalities Survivors }\end{array}$} & \multicolumn{2}{|c|}{$\begin{array}{l}\text { Immersion } \\
\text { Mortalities Survivors }\end{array}$} & \multicolumn{2}{|c|}{$\begin{array}{l}\text { i.p. control } \\
\text { Mortalities Survivors }\end{array}$} & \multicolumn{2}{|c|}{$\begin{array}{l}\text { Immersion control } \\
\text { Mortalities Survivors }\end{array}$} \\
\hline & $90 / 90$ & $0 / 90$ & $54 / 90$ & $36 / 90$ & $64 / 90$ & $26 / 90$ & $1 / 30$ & $29 / 30$ & $0 / 30$ & $30 / 30$ \\
\hline $\begin{array}{l}\text { Proportion of organ pools tested } \\
\text { resulting in tissue culture CPE }\end{array}$ & $\begin{array}{c}90 / 90 \\
(100 \%)\end{array}$ & - & $\begin{array}{c}48 / 54 \\
(88.9 \%)\end{array}$ & $\begin{array}{l}0 / 18 \\
(0 \%)\end{array}$ & $\begin{array}{c}58 / 64 \\
(90.6 \%)\end{array}$ & $\begin{array}{l}0 / 13 \\
(0 \%)\end{array}$ & $\begin{array}{c}0 / 1 \\
(0 \%)\end{array}$ & $\begin{array}{l}0 / 15 \\
(0 \%)\end{array}$ & - & $\begin{array}{l}0 / 15 \\
(0 \%)\end{array}$ \\
\hline $\begin{array}{l}\text { Proportion of organ pool CPEs } \\
\text { tested positive by ELISA. }\end{array}$ & $30 / 30$ & - & $24 / 24$ & - & $26 / 26$ & - & $0 / 1$ & - & - & - \\
\hline $\begin{array}{l}\text { Proportion of brain pools tested } \\
\text { resulting in tissue culture CPE }\end{array}$ & $\begin{array}{c}28 / 29 \\
(96.6 \%)\end{array}$ & - & $\begin{array}{c}41 / 44 \\
(93.2 \%)\end{array}$ & $\begin{array}{l}0 / 18 \\
(0 \%)\end{array}$ & $\begin{array}{c}53 / 54 \\
(98.1 \%)\end{array}$ & $\begin{array}{l}0 / 13 \\
(0 \%)\end{array}$ & $\begin{array}{c}0 / 1 \\
(0 \%)\end{array}$ & $\begin{array}{l}0 / 15 \\
(0 \%)\end{array}$ & - & - \\
\hline $\begin{array}{l}\text { Proportion of brain pool CPES } \\
\text { tested positive by ELISA }\end{array}$ & $18 / 18$ & - & $22 / 22$ & - & $25 / 25$ & - & $0 / 1$ & - & - & - \\
\hline
\end{tabular}


injected fish to 1 non-injected fish. In another tank, 15 fish were removed, marked as above and shaminjected with $100 \mu$ l GMEM-10. These fish were returned to cohabit with the remaining 15 non-injected fish to serve as a control.

An immersion challenge was performed using an additional 3 tanks of fish. Water flow was stopped and the tanks drained to a volume of $10 \mathrm{l}$. Virus diluted in GMEM-10 was added to each tank to achieve a dose of $8 \times 10^{4} \mathrm{ml}^{-1}$. After $3 \mathrm{~h}$, flow rates were returned to normal, and the tank volumes allowed to return to $30 \mathrm{l}$. A fourth tank of fish received a control immersion infection performed in a similar manner using an equivalent volume of GMEM-10 containing no virus.

Sampling regime. Dead and moribund fish were removed and recorded daily from all tanks for the duration of the challenge $(87 \mathrm{~d})$. Brain and organs (kidney, liver and spleen) from all individual dead and moribund turbot were obtained in separate pools for virological examination. All i.p. and $50 \%$ of cohabiting turbot surviving at the end of the infection period were sacrificed and samples taken for virological examination.

Virus recovery and identification. Wells of EPC cells grown on 24 -well plates to a confluency of 60 to $80 \%$, were inoculated with tissue samples diluted to final dilutions of $1: 100$ and $1: 1000$ as detailed previously. Following a second passage on EPC cells, the presence of CPE was again recorded.

Tissue culture supernatants from wells exhibiting CPE were tested by an ELISA specific for VHSV. The sample size required to estimate the proportion of cultures exhibiting CPE due to VHSV was determined at the $95 \%$ confidence level (Table 1) using the method described by Thompson (1992). This method was based on the assumption that at least $50 \%$ of cultures exhibiting CPE were due to VHSV. A commercially available ELISA kit was used for identification of VHSV antigen according to the manufacturers' instructions (Test-Line Clinical Diagnostics, Brno, Czech Republic). The optical density of each well was read at $450 \mathrm{~nm}$ against a blank sample on a DIAS plate reader using the Revelation software (Dynex Technologies). Samples were recorded as positive if the absorbance value was greater than twice that of the negative control.

\section{RESULTS}

\section{Infection of turbot with VHSV isolate $860 / 94$}

Turbot were confirmed, by virological examination, to be free from VHSV, IHNV and IPNV prior to infection. Cumulative percent mortalities of replicate

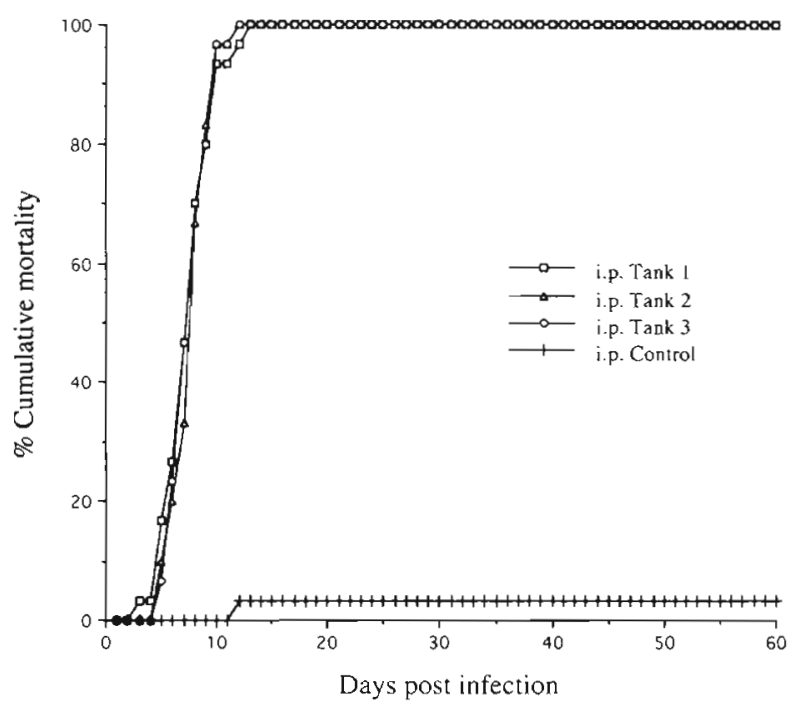

Fig. 1. VHSV infecting Scophthalmus maximus. Percent cumulative mortality recorded in individual tank replicates of turbot infected with VHSV isolate $860 / 94$ via the intra-peritoneal route (i.p.). No mortalities were recorded after Day 60 post-infection

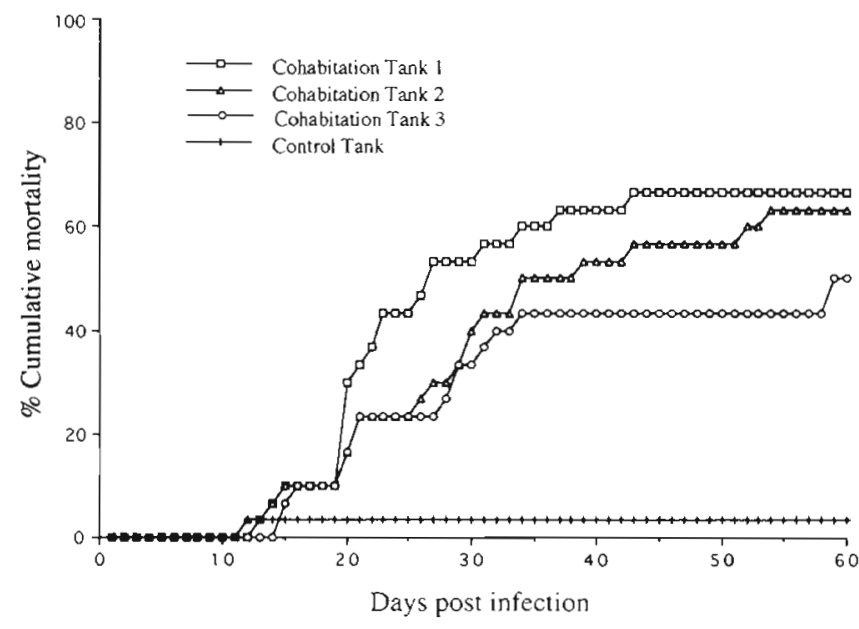

Fig. 2. VHSV infecting Scophthalmus maximus. Percent cumulative mortality recorded in individual tank replicates of turbot cohabiting with fish infected with VHSV isolate $860 / 94$ via the intra-peritoneal route (i.p.). No mortalities were recorded after Day 60 post-infection

groups of immersion infected, i.p. infected and cohabiting turbot are shown in Figs. 1 \& 2. In the i.p. infection challenge, mortalities commenced between 3 and $5 \mathrm{~d}$ post-infection, and reached $100 \%$ by $13 \mathrm{~d}$ in all tank replicates (Fig. 1). In these same tanks, mortalities amongst cohabiting fish commenced between 12 and $15 \mathrm{~d}$ following exposure to VHSV-infected individuals (Fig. 2). The mortality rate in cohabiting fish was lower than that of i.p. infected fish, and the total mortality in each replicate reached between 50 and $67 \%$ at the end 


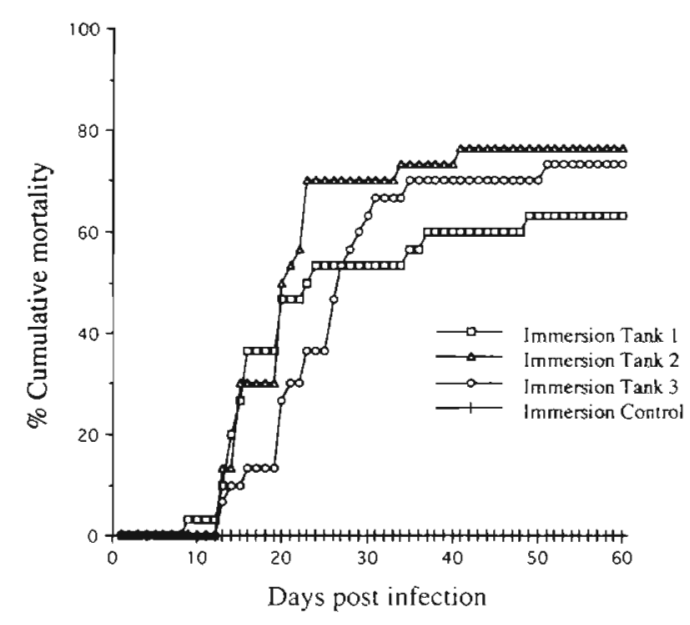

Fig. 3. VHSV infecting Scophthalmus maximus. Percent cumulative mortality recorded in individual tank replicates of turbot infected by immersion with isolate 860/94. No mortalities were recorded after Day 60 post-infection

of the experimental infection. A single mortality was recorded in the control fish at $12 \mathrm{~d}$ post-infection.

In the immersion infections, mortality commenced between 9 and $13 \mathrm{~d}$ in all tank replicates (Fig. 3). Mean cumulative mortalities in each tank reached between 63 and $74 \%$ at the end of the infection period. No mortality was recorded in the control fish for the duration of the experiment.

Moribund turbot which had been subjected to all 3 methods of viral infection exhibited signs of clinical VHS similar to those previously reported in turbot (Castric \& de Kinkelin 1984). These signs included a darkening of the skin and the presence of haemorrhaging around the head and fin bases.

\section{Statistical analyses}

Statistical analyses were conducted using a generalised linear regression as implemented in the Genstat 5 (Release 3) computer software. The effect of a single main parameter (mortality treatment) within turbot infected by the i.p. or cohabitational route was assessed based on binomially distributed data using the logistic link function. A residual deviance of 3.3 on 6 degrees of freedom, indicated no overdispersion or lack of fit. A highly significant treatment effect was identified $(\mathrm{p}=0.001)$. A significantly higher mortality was indicated $(p=0.05)$ in i.p. virus-injected fish than in cohabiting, immersion or control infected fish. Mortality in cohabiting or immersion virus-challenged groups was not significantly different from each other, but both were significantly different from control groups $(\mathrm{p}=0.05)$.

\section{Virus recovery and identification}

The numbers of dead and surviving fish examined for virus recovery are detailed in Table 1 . Virus was recovered from 100 and $96.6 \%$ of the organ and brain samples, respectively, taken from dead i.p. injected turbot, as indicated by a production of a cytopathic effect in EPC cells. Similarly, virus was detected in 88.9 and $93.2 \%$ of organ and brain samples taken from turbot cohabiting with i.p. infected fish. In the immersioninfected fish, virus was detected in 90.6 and $98.1 \%$ of the organ and brain samples, respectively. No virus was recoverable from any of the control i.p. or immersion-infection fish tested. Similarly, no virus was detectable in any of the cohabiting or immersion-infected fish surviving at the end of the experimental infection period.

Testing of cell culture supernatants from apparent virus-positive brain or organ samples indicated that all samples were positive for VHSV antigen. Cell culture supernatants obtained from the single control fish mortality were negative for VHSV by ELISA.

\section{DISCUSSION}

Pathogen-free juvenile turbot were highly susceptible to the VHSV isolate $860 / 94$ by intra-peritoneal, cohabitational and waterborne infection. The virus was reisolated from fish which died in all 3 experimental infections, and was identified as VHSV by ELISA, thus fulfilling Rivers' postulates (Rivers 1937). Diseased turbot displayed signs of VHSV similar to those first described in turbot by Castric \& de Kinkelin (1984). The high level of mortality following infection by i.p. injection in this study was comparable to that obtained by these authors, who challenged turbot with isolate 07/71, which originated from rainbow trout Oncorhynchus mykiss (Le Berre et al. 1977). Mortality resulting from immersion infection with this isolate were however less than half that obtained in this study. Experimental immersion infections have further indicated rainbow trout to be highly susceptible to isolate 07-71 (Bernard et al. 1983), but resistant to isolate $860 / 94$ ( N. Olesen pers. comm.). These results indicate the existence of differing mechanisms governing the uptake and/or replication of VHSV isolate 860/94 in turbot and rainbow trout following waterborne challenge. However, the basis for this observed difference in pathogenicity remains to be clarified.

Although the i.p. route ensures delivery of a standardised viral dose, virus infection via cohabitation or immersion routes better reflect natural VHSV infection, which is thought to occur largely by horizontal transmission of waterborne virus (Wolf 1988). Thus, 
our demonstration that turbot are susceptible to VHSV by cohabitation closely mimics natural exposure to the pathogen in which specific and non-specific immune mechanisms located in the skin and other body surfaces exert their role. The susceptibility of turbot to infection and disease from VHSV by both cohabitation and immersion provides evidence for the shedding of virus by i.p. infected fish and for the ability of the virus to survive in sea water and infect fish via horizontal transmission. Virus shedding in static sea water at levels of $>10^{6.5} \mathrm{pfu} \mathrm{h}^{-1} \mathrm{fish}^{-1}$ has been demonstrated for Pacific herring (Kocan et al. 1997), whilst marine VHSV can survive from 7 to $21 \mathrm{~d}$ in sea water at $4{ }^{\circ} \mathrm{C}$ (Parry \& Dixon 1997). Thus, horizontal transmission of virus in sea water may represent an important mechanism by which VHSV is disseminated in the marine environment.

Although this study has demonstrated the experimental susceptibility of turbot to the VHSV isolate $860 / 94$, mortality rates recorded during the outbreak from which this isolate originated were low (Munro 1996). This may have been due to the use of juvenile fish in the experimental challenge, whereas mortalities recorded in the Gigha outbreak were in fish up to $1.9 \mathrm{~kg}$ (Munro 1996). In addition, the experimental doses administered were likely to be considerably higher than exposure levels in a natural VHS outbreak. The effect of propagation of viruses known to exist as quasispecies populations on homogeneous fish cell lines also remains unclarified. Thus, the possibility exists that the isolate used for experimental infection, which was amplified by 2 passages in EPC cells, does not reflect the true composition of the isolate repsonsible for causing mortality under field conditions.

Virus identified as VHSV by ELISA, was recovered from both the organs and brains of fish tested from all 3 infection methods. The recovery of VHSV from the brain of infected turbot is in contrast to the reported findings of Castric \& de Kinkelin (1984). Although these authors recovered VHSV from experimentally infected sea bass in which a neural form of disease occurred, no virus was recovered from the brains of infected turbot. These differences may be due to the fact that a different viral strain originating from rainbow trout was used in the latter study. Thus, these viruses may exhibit different tissue tropisms in turbot either facilitating or blocking invasion of the nervous tissue, respectively. Indeed, the existence of different tissue tropisms, for isolates of both VHSV and the related fish novirhabdovirus IHNV (LaPatra et al. 1995) have been demonstrated.

The finding of VHSV in the brain of infected fish species supports previous studies demonstrating the multiplication of VHS virus in the brain of infected rainbow trout, and the presence of virus in the brain more than $400 \mathrm{~d}$ after experimental infection (Neukirch $1984,1986)$. That virus has been demonstrated to occur in the brain of marine species may also have significance in the epizootiology of VHSV in wild fish. If VHSV can reside in nervous tissue, it may escape immunodetection and result in persistent infection. Indeed, in the case of IHNV, virus persistence has been implicated in the cyclical reappearance of clinical disease which is associated with certain stressors (Leong 1995). Similarly, the epizootiology of VHSV in Pacific herring also appears to be that of an opportunistic pathogen triggered by stress (Meyers et al. 1994, Meyers \& Winton 1995). Given the association of VHSV and stress in wild fish and demonstrated susceptibility of turbot to VHSV, fish reared under intensive culture regimes may be particularly at risk to VHSV that is present in the marine environment.

This study has demonstrated a number of infection models applicable to investigation of the experimental susceptibility of marine fish species to VHSV. Findings that virus may persist in the brain of infected marine fish species have important implications with regard to the maintenance of VHSV in wild fish populations. The fact that turbot were shown to be highly susceptible to VHSV via a route which mimics natural infection, highlights the potential risk presented to cage-based farming of susceptible fish species in an environment where VHSV is ubiquitous. Given the existence of a marine reservoir of VHSV in Europe, coupled with the demonstration that turbot are susceptible to this virus, the development of vaccination strategies against VHSV may be of considerable importance to future commercial turbot production. The development of a waterborne infection model for turbot is thus of fundamental importance in determining the efficacy of such experimental vaccines.

\section{LITERATURE CITED}

Bernard J, de Kinkelin P, Bearzotti-Le Berre M (1983) Viral hemorrhagic septicemia of rainbow trout: relation between the $G$ polypeptide and antibody production in protection of the fish after infection with the F25 attenuated variant. Infect Immun 39;7-14

Burleson FG, Chambers TM, Wiedbrauk DL (1992) Virology, a laboratory manual. Academic Press, London

Castric J, de Kinkelin P (1984) Experimental study of the susceptibility of two marine fish species, sea bass (Dicentrarchus labrax) and turbot (Scophthalmus maximus) to viral haemorrhagic septicaemia. Aqua 41:203-212

de Kinkelin P, Castric J (1982) An experimental study of the susceptibility of Atlantic salmon fry, Salmo salar L., to viral haemorrhagic septicaemia. J Fish Dis 5:57-65

Dixon PF, Feist S, Kehoe E, Parry L, Stone DM, Way K (1997) Isolation of viral haemorrhagic septicaemia virus from Atlantic herring Clupea harengus from the English Channel. Dis Aquat Org 30:81-89

Fijan N, Sulimanovic D, Bearzotti M, Muzinic D, Zwillenberg 
LO, Chilmonczyk S, Vautherot JF, de Kinkelin P (1983) Some properties of the epithelioma papulosum cyprini (EPC) cell line from carp (Cyprinus carpio). Ann Inst Pasteur/Virol 134:207-220

Kocan R, Bradley $M$, Elder N, Meyers T, Batts B, Winton J (1997) North American strain of viral hemorrhagic septicemia virus is highly pathogenic for laboratory-reared Pacific herring. J Aquat Anim Health 9:279-290

LaPatra SE, Lauda KA, Jones GR, Walker SC, Shewmaker BS, Morton AW (1995) Characterisation of IHNV isolates associated with neurotropism. Vet Res 26:433-437

Le Berre $M$, de Kinkelin P, Metzger A (1977) Identification serologique des rhabdovirus des salmonides. Bull Off Int Epizoot 87:391-393

Leong JC (1995) Molecular biological tools to detect fish pathogens. J Fish Biol 47:61-75

Meyers TR, Winton JR (1995). Viral hemorrhagic septicemia in North America. Annu Rev Fish Dis 5:3-24

Meyers TR, Short S, Lipson K, Batts WN, Winton JR, Wilcock $J$, Brown E (1994) Association of viral hemorrhagic septicemia virus with epizootic haemorrhages of the skin in Pacific herring Clupea harengus pallasi from Prince William Sound and Kodiak Island, Alaska, USA. Dis Aquat Org 19:27-37

Mortensen HF, Heur OE, Lorenzen N, Otte L, Olesen NJ (1999) Isolation of viral haemorrhagic septicaemia virus from wild marine fish species in the Baltic sea, Kattegat, Skagerrak and the North Sea. Vir Res 63:95-106

Munro ALS (1996) Report on the first recorded outbreak of viral haemorrhagic septicemia (VHS) in GB and subsequent actions to contain, eradicate and investigate the origins of the infection. Scottish Aquaculture Research Report Number 3. The Scottish Office Agriculture, Environment and Fisheries Department, Aberdeen

Neukirch $M$ (1984) An experimental study of the entry and

Editorial responsibility: Jo-Ann Leong,

Corvallis, Oregon, USA multiplication of viral haemorrhagic septicaemia virus in rainbow trout, Salmo gairdneri, Richardson, after waterborne infection. J Fish Dis 7:231-234

Neukirch M (1986) Demonstration of persistent viral haemorrhagic septicaemia (VHS) virus in rainbow trout after experimental waterborne infection. J Vet Med 33:471-476

Parry L, Dixon PF (1997) Stability of nine viral haemorrhagic septicaemia virus (VHSV) isolates in sea water. Bull Eur Assoc Fish Pathol 17:31-36

Reed LJ, Muench H (1938). A simple method of estimating fifty percent endpoints. Am J Hyg 27:493-497

Rivers TM (1937) Viruses and Koch's postulates. J Bacteriol 33:1-12

Ross K, McCarthy U, Huntly PJ, Wood BP, Stuart D, Rough EI, Smail DA, Bruno DW (1994) An outbreak of viral haemorrhagic septicaemia (VHS) in turbot (Scophthalmus maximus) in Scotland. Bull Eur Assoc Fish Pathol 14:213

Smail DA (1995). Isolation and identification of viral haemorrhagic septicaemia (VHS) virus from north sea cod (Gadus morhua L.). ICES CM 1995/F:15

Snow M, Cunningham CO, Melvin WT, Kurath G (1999) Analysis of the nucleoprotein gene, identifies distinct lineages of viral haemorrhagic septicaemia virus (VHSV) within the European marine environment. Vir Res 63: $35-44$

Stone DM, Way K, Dixon PF (1997) Nucleotide sequence of the glycoprotein gene of viral haemorrhagic septicaemia (VHS) viruses from different geographical areas: a link between VHS in farmed fish species and viruses isolated from North Sea cod (Gadus morhua L.). J Gen Virol 78: $1319-1326$

Thompson S (1992) Sampling. Wiley series in probability and mathematical statistics. J Wiley and Sons Inc, New York

Wolf K (1988) Fish viruses and fish viral diseases. Cornell University Press, Ithaca

Submitted: June 25, 1999; Accepted: September 8, 1999 Proofs received from author(s): October 25, 1999 